\title{
Ecological ramifications of the direct foliar uptake of nitrogen
}

\author{
Jed P. Sparks
}

Received: 26 June 2008/ Accepted: 29 September 2008/Published online: 31 October 2008

(C) Springer-Verlag 2008

\begin{abstract}
The foliar incorporation of various reactive forms of nitrogen $(\mathrm{N})$ has been identified and studied for nearly 30 years. However, the ecosystem-level ramifications of this uptake pathway have only recently been considered by the scientific community. In this review, I present our current understanding of the foliar uptake process and then discuss why this pathway of $\mathrm{N}$ addition to ecosystems should be considered separately from the bulk deposition of $\mathrm{N}$ to the soil surface. Direct foliar uptake is a direct addition of $\mathrm{N}$ to plant metabolism and could potentially more readily influence plant growth compared to soildeposited N. Current ecosystem process models do not partition reactive $\mathrm{N}$ between foliar and soil entry pathways and the influence of $\mathrm{N}$ deposition on ecosystem $\mathrm{C}$ sequestration is likely inadequately represented in most models. I also outline several research priorities for the future understanding of the ecological consequences of foliar uptake of reactive $\mathrm{N}$.
\end{abstract}

Keywords Nitrogen $\cdot$ Nitrogen dioxide $\cdot$ Nitric acid · Peroxyacetyl nitrate $\cdot$ Ammonia

\section{Introduction}

Throughout history, the lack of reactive nitrogen $(\mathrm{N})$ has largely limited the food production needed to sustain

Communicated by Robert Pearcy.

J. P. Sparks $(\square)$

Department of Ecology and Evolutionary Biology,

Cornell University, Corson Hall Room E149, Ithaca,

NY 14853-2701, USA

e-mail: jps66@cornell.edu human population growth. A desire to increase food production by the use of fertilizer and the increase in the use of fossil fuels has led to an excess in reactive $\mathrm{N}$ delivered to the biosphere each year, resulting in a array of human health and ecological issues (e.g., Cowling et al. 2001; Galloway et al. 2003, 2008; Erisman et al. 2007).

One major ramification of increased global reactive $\mathrm{N}$ is a large increase in the reactive $\mathrm{N}$ gases delivered to the atmosphere each year and the eventual deposition of this reactive $\mathrm{N}$ back to the earth's surface. Galloway et al. (2004) suggest that total global atmospheric deposition of reactive $\mathrm{N}$ increased from 31.6 to $103 \mathrm{Tg} \mathrm{N}$ year $^{-1}$ from 1860 to the mid-1990s and is expected to further increase to $195 \mathrm{Tg} \mathrm{N}$ year $^{-1}$ by 2050 .

The response of entire ecosystems to added reactive $\mathrm{N}$ is the subject of a large and varied body of literature (e.g., Holland and Lamarque 1997; Aber et al. 2003; Galloway et al. 2004) and well beyond the scope of this review. The current review was prepared with the following goals in mind: to summarize the existing literature describing the foliar incorporation of reactive $\mathrm{N}$, to present several arguments for why foliar and soil pathways of $\mathrm{N}$ incorporation into biota should be considered separately, and to suggest future avenues of research to more fully elucidate the importance of canopy incorporation of $\mathrm{N}$.

\section{The sources of reactive $\mathrm{N}$ in the atmosphere}

Oxidized forms of $\mathrm{N}\left(\mathrm{NO}_{y}\right)$ and ammonia $\left(\mathrm{NH}_{3}\right)$ emissions to the atmosphere result from natural sources, food production, and the generation of energy (Galloway et al. 2004). Total $\mathrm{NO}_{y}$ emissions to the atmosphere are currently estimated to be $\sim 46 \mathrm{Tg} \mathrm{N}$ year $^{-1}$ with the largest contribution coming from the combustion of fossil fuels 
$\left(\sim 20 \mathrm{Tg} \mathrm{N}\right.$ year $^{-1}$ ). Total $\mathrm{NH}_{3}$ emissions to the atmosphere are $\sim 57 \mathrm{Tg} \mathrm{N}$ year $^{-1}$ with the largest contribution coming from volatilization from animal wastes ( $\sim 23 \mathrm{Tg} \mathrm{N}$ year $^{-1}$ ) (van Aardenne et al. 2001). Both of these estimates are increasing with time and are predicted to be $>50 \%$ larger by 2050 (Galloway et al. 2004).

The various forms of $\mathrm{NO}_{y}$ and $\mathrm{NH}_{3}$ are reactive gases that readily deposit back to the surface at relatively short time scales (minutes to days) after emission. Global deposition estimates (Lelieveld and Dentener 2000) reflect this rapid deposition and suggest a large proportion of all emissions are deposited back to the surface on a less than annual time scale.

Plant cover plays an important and controlling role in the rate of deposition of most reactive compounds including N. In general, plant canopies greatly increase the rate of deposition. However, the ultimate rates at which reactive $\mathrm{N}$ compounds are transferred between the atmosphere and the surface are the result of several interconnected ecological, biochemical, chemical, and edaphic controls and the overarching meteorological conditions. The challenges associated with the measurement and modeling of these fluxes has been at the forefront of ecology, biometeorology and biogeochemistry for two decades and much uncertainty still exists (e.g., Baldocchi and Wilson 2001; Monson and Holland 2001). However, there is little doubt that some proportion of the downward flux of reactive compounds interacts with, and may be absorbed, by plant canopies.

\section{Historical perspective of foliar uptake}

The role of atmospheric deposition in plant nutrition has been acknowledged and described for nearly 200 years (e.g., Von Liebig 1827). However, the foliar uptake of $\mathrm{N}$ was not studied intensively until the mid-twentieth century. With the general recognition of $\mathrm{N}$-based air pollution, plant scientists described the foliar interactions with several reactive N compounds (Dugger et al. 1963; Hill and Bennett 1970; Spierings 1971; Wellburn et al. 1972; Zeevaart 1976 among others). The pioneering work of these early authors led to two observations that have guided much of the research in the field: at some atmospheric concentration, reactive $\mathrm{N}$ compounds cause phytotoxicity; the endpoint chemical products formed in the apoplast during fumigation [most commonly nitrite $\left(\mathrm{NO}_{2}{ }^{-}\right)$, nitrate $\left(\mathrm{NO}_{3}{ }^{-}\right)$, and ammonium $\left.\left(\mathrm{NH}_{4}^{+}\right)\right]$are compounds assimilated by the normal plant $\mathrm{N}$ assimilation pathways. Therefore, the potential for both detrimental and beneficial, through fertilization, effects of foliar uptake have been considered since the earliest measurements.

Most of the early experiments were laboratory fumigations of entire plants. Due to the technology available for both gas production and measurements, these experiments were done at high concentrations, well above those observed in the field. Therefore, phytotoxic leaf damage was often observed. For example, Zeevaart (1976) described necrotic leaf damage of up to $87 \%$ in several herbaceous plant species after 2 days of fumigation. However, the fumigation level used in this experiment was 4-11 p.p.m. (a level 100 times higher than that currently observed in the atmosphere). Interestingly, during this same experiment, Zeevaart (1976) observed large increases in the $\mathrm{NO}_{2}{ }^{-}$content of leaves, leaving open the possibility of plant fertilization even at these unnaturally high levels of fumigation.

These early experiments provided insight into many of the phytotoxic effects of reactive $\mathrm{N}$ and described much of the mechanisms of uptake. However, it was not until the past 25 years that adequate methodologies for controlling and monitoring gas concentration at levels representative of the atmosphere were applied to physiological measurements.

\section{Physiological ecology of foliar uptake}

\section{Uptake mechanisms}

Figure 1 describes the general understanding of the leaf uptake pathways of oxidized and reduced forms of reactive $\mathrm{N}$. Nitric oxide (NO), nitrogen dioxide $\left(\mathrm{NO}_{2}\right)$, and $\mathrm{NH}_{3}$ dissolve in the leaf apoplast to primarily form nitrous acid $\left(\mathrm{HONO}, \mathrm{HNO}_{2}\right)$ and nitric acid $\left(\mathrm{HNO}_{3}\right)$ that then dissociate to $\mathrm{NO}_{2}{ }^{-}, \mathrm{NO}_{3}{ }^{-}$, and protons and $\mathrm{NH}_{4}{ }^{+}$, respectively (Zeevaart 1976; Wellburn 1990; Gessler and Rennenberg 1998). The $\mathrm{NO} / \mathrm{NO}_{2}$ reaction is irreversible and dependent upon the concentration of $\mathrm{NO}_{2}{ }^{-} / \mathrm{NO}_{3}{ }^{-}$in the apoplastic solution (Remmler and Campbell 1986; Stulen et al. 1998). The dissolution of $\mathrm{NH}_{3}$ into the leaf apoplast is driven by the gradient in concentration between the $\mathrm{NH}_{3}$ concentration in the air of the substomatal space and the surrounding mesophyll tissue. This gradient is variable depending upon the ambient $\mathrm{NH}_{3}$ concentration and in many areas far from point sources of $\mathrm{NH}_{3}$, a net emission of $\mathrm{NH}_{3}$ is observed from leaves. This suggests $\mathrm{NH}_{3}$ has a leaf-level compensation point (Krupa 2003). A compensation point has also been reported for $\mathrm{NO}_{2}$ (Thoene et al. 1991; Sparks et al. 2001; Teklemariam and Sparks 2006) but it is usually small $(<50 \mathrm{pmol})$ and often does not appear congruent with whole canopy estimates (Lerdau et al. 2000). It has been suggested there is some level of storage (in the apoplast or in cellular vacuoles) of $\mathrm{NO}_{3}{ }^{-}$and $\mathrm{NH}_{4}{ }^{+}$before eventual assimilation (Grundmann et al. 1993; Qiao and Murray 1997). However, these studies were conducted at very high concentrations and similar storage has not been reported in studies conducted at realistic atmospheric concentrations. 


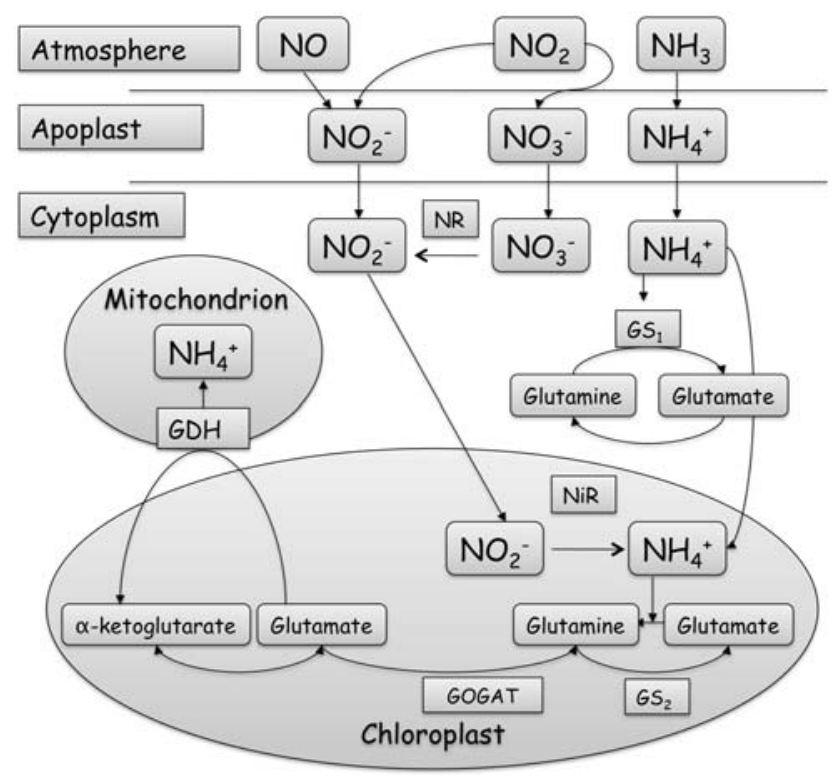

Fig. 1 Primary biochemical processes describing the foliar uptake and assimilation of atmospheric ammonia $\left(\mathrm{NH}_{3}\right)$, nitric oxide $(\mathrm{NO})$, and nitrogen dioxide $\left(\mathrm{NO}_{2}\right)$. Adapted from Stulen et al. (1998). $G S_{1}$ Cytosolic isoform of glutamine synthetase, $G S_{2}$ chloroplastic isoform of GS, $N R$ nitrate reductase, $N i R$ nitrite reductase, GOGAT glutamate synthase, $\mathrm{NO}_{2}{ }^{-}$nitrite, $\mathrm{NO}_{3}{ }^{-}$nitrate, $\mathrm{NH}_{4}{ }^{+}$ammonium

Once in the apoplast, $\mathrm{NH}_{4}{ }^{+}$is transported into the cell and assimilated by the glutamine synthetase (GS) and glutamate synthase (GOGAT) systems (Lea and Miflin 1974; Tischner 1987; Wallsgrove 1987; Krupa 2003). The other major source of $\mathrm{NH}_{3}$ in the cytosol is photorespiratory and, as such, the $\mathrm{NH}_{3}$ derived from foliar uptake interacts directly with photorespiratory processes. Glutamate dehydrogenase has also been suggested as an alternative to the GS/GOGAT system (Srivastava and Singh 1987; Stulen et al. 1998), but appears to play a minor role in the assimilation of atmospheric $\mathrm{NH}_{3}$ (Rhodes et al. 1989; Krupa 2003). GS is often found in plants as two isoforms, one cytosolic and the other chloroplastic (Fig. 1). The relative importance of $\mathrm{GS}_{1}$ and $\mathrm{GS}_{2}$ varies across plant species (Miflin and Habash 2002) and both may be involved in the assimilation of $\mathrm{NH}_{3}$.

After dissolution to $\mathrm{NO}_{2}{ }^{-}$and $\mathrm{NO}_{3}{ }^{-}$from $\mathrm{NO}_{2}$ in the apoplast, both forms are transported into the cell where $\mathrm{NO}_{3}{ }^{-}$is rapidly reduced to $\mathrm{NO}_{2}{ }^{-}$by the enzyme nitrate reductase (Stulen and ter Steege 1995). $\mathrm{NO}_{2}{ }^{-}$is then transported into the chloroplast and reduced to $\mathrm{NH}_{4}{ }^{+}$by nitrite reductase and eventually incorporated into plant proteins (Lea et al. 1994; Fig. 1). The source of $\mathrm{NO}_{3}{ }^{-}$in the leaf can therefore be from both foliar uptake and root transport. However, many trees, especially conifers, preferentially absorb $\mathrm{NH}_{3}$ at the root surface or reduce $\mathrm{N}$ in the roots and do not transport appreciable amounts of $\mathrm{NO}_{3}{ }^{-}$in the xylem to the leaves. Therefore, in these species, atmospheric $\mathrm{N}$ may be the only or most significant source of $\mathrm{NO}_{3}{ }^{-} / \mathrm{NO}_{2}{ }^{-}$to the leaves.

$\mathrm{NH}_{4}{ }^{+}$and $\mathrm{NO}_{3}{ }^{-}$accumulate on leaf surfaces from the dry deposition of both gases and particles (Davidson and $\mathrm{Wu}$ 1990; Bobbink et al. 1992). A large body of evidence comparing bulk deposition to canopy throughfall has suggested an uptake of leaf-surface N (e.g., Lovett et al. 1985; Garten and Hanson 1990; Bobbink et al. 1992 among others). However, the mechanisms of how these ions enter the leaf are still unclear. Often throughfall measurements reveal a net release of other ions (e.g., $\mathrm{K}^{+}, \mathrm{Mg}^{2+}, \mathrm{Ca}^{2+}$ ) suggesting a process of cation exchange in the canopy. Diffusion through stomata and cuticular transport have also been suggested as mechanisms (Bowden et al. 1989; Boyce et al. 1996).

The uptake mechanisms governing the leaf uptake of $\mathrm{HNO}_{3}$ vapor have remained elusive due to the extreme reactivity of this compound. A large body of literature using primarily micrometeorological techniques has provided estimates of total $\mathrm{HNO}_{3}$ flux to ecosystems (e.g., Meyers et al. 1989; Janson and Granat 1999; Sievering et al. 2001; Pryor et al. 2004). However, these methods do not necessarily help to elucidate the uptake mechanisms at the leaf level. Mechanistic work has suggested $\mathrm{HNO}_{3}$, in contrast to other reactive $\mathrm{N}$ gases, is primarily deposited to the cuticle rather than taken up via stomata (Dasch 1989; Marshall and Cadle 1989). Modeling based on the chemical characteristics of $\mathrm{HNO}_{3}$ (Taylor et al. 1988; Hanson and Taylor 1990) and ${ }^{15} \mathrm{~N}-\mathrm{HNO}_{3}$ tracer studies (e.g., Vose and Swank 1990) have further supported that $\mathrm{HNO}_{3}$ is primarily deposited to leaf cuticles.

Leaf uptake of HONO has been reported (Schimang et al. 2006) and the pathway of assimilation would likely be similar to that of $\mathrm{NO}_{2}$. The leaf uptake of the organic form of nitrogen peroxyacetyl nitrate $\left(\mathrm{CH}_{3} \mathrm{C}(\mathrm{O}) \mathrm{O}_{2} \mathrm{NO}_{2}\right.$; PAN) has also been described (Okano et al. 1990; Sparks et al. 2003; Teklemariam and Sparks 2004). These authors suggest the assimilatory pathway after incorporation into the leaf apoplast would mirror that for $\mathrm{NO}_{2}$. However, the mechanism of how PAN disassociates into the apoplastic water remains unresolved.

\section{Leaf-level controls}

The primary control over the foliar uptake rate of most reactive $\mathrm{N}$ gases is the size of the stomatal aperture. The rate of the uptake of $\mathrm{NO}_{2}$ into the leaf has been reported to be strongly related to stomatal conductance in a multitude of studies (Saxe 1986; Hanson and Lindberg 1991; Hargreaves et al. 1992; Weber and Rennenberg 1996; Sparks et al. 2001; Gut et al. 2002; Teklemariam and Sparks 2006; Eller and Sparks 2006 among others). This relationship appears to be linear for most plants and is the primary factor controlling the magnitude of flux into the leaf. Similarly, the leaf uptake of 
gaseous $\mathrm{NH}_{3}$ is strongly controlled by the stomatal aperture (Duyzer et al. 1994; Hanstein et al. 1999; Gessler et al. 2000, 2002). However, as described in "Uptake mechanisms", the concentration of $\mathrm{NH}_{4}^{+}$in the apoplastic water strongly influences the flux rate (and direction) of $\mathrm{NH}_{3}$ flux and the strong control of stomatal conductance is often minimized under physiological or environmental conditions leading to high apoplastic $\mathrm{NH}_{4}{ }^{+}$concentrations (Gessler and Rennenberg 1998; Wyers and Erisman 1998; Herrmann et al. 2001). Although the complete uptake mechanisms have yet to be elucidated for HONO and organic forms or reactive $\mathrm{N}$ (primarily PAN), the leaf uptake of both of these gases is strongly related to stomatal aperture (Sparks et al. 2003. Schimang et al. 2006; Teklemariam and Sparks 2006). Because of high reactivity, the flux of $\mathrm{HNO}_{3}$ is often unrelated to stomatal conductance (Meyers et al. 1989; Pryor and Klemm 2004). The flux of particulate forms of $\mathrm{NH}_{4}{ }^{+}$and $\mathrm{NO}_{3}{ }^{-}$into leaves is likely related to the stomatal aperture. However, this relationship has yet to be demonstrated experimentally.

After stomatal resistance to diffusion, the strongest control over leaf uptake of reactive $\mathrm{N}$ gases is the dissolution of the gases into the apoplastic water and transport into mesophyll cells. Several authors have suggested resistance at the level of the mesophyll to plant uptake (Thoene et al. 1991, 1996; Hereid and Monson 2001; Sparks et al. 2001; Gut et al. 2002; Teklemariam and Sparks 2006; Eller and Sparks 2006). The primary hypotheses presented have proposed antioxidant compounds in the apoplast facilitating rapid uptake (Ramge et al. 1993; Teklemariam and Sparks 2006; Eller and Sparks 2006; Haberer et al. 2006) and regulation of the transport and consumption of the apoplastic endpoint products $\left(\mathrm{NO}_{2}{ }^{-}, \mathrm{NO}_{3}{ }^{-}\right.$, and $\left.\mathrm{NH}_{4}{ }^{+}\right)$by downstream enzymatic activity (Zeevaart 1976; Murray and Wellburn 1985; Rowland et al. 1987; Bender et al. 1991; Thoene et al. 1991; Hur and Wellburn 1994; Hufton et al. 1996; Wellburn 2002; Eller and Sparks 2006). Eller and Sparks (2006) suggested the uptake of $\mathrm{NO}_{2}$ to leaves could be predicted with fidelity using a correlative model considering stomatal conductance, apoplastic ascorbate, and leaf nitrate reductase activity. However, this model described only a single plant species and it is unclear if such a model would be applicable across multiple plant species or functional types.

Leaf- and canopy-level fluxes of $\mathrm{NH}_{3}$ are usually modeled using a compensation model originally developed by Sutton et al. (1998). This is a canopy resistance model that uses a stomatal compensation point for $\mathrm{NH}_{3}$ and soil emission. The stomatal compensation point is calculated (see Nemitz et al. 2000) as a function of temperature and the leaf emission potential (the ratio of $\mathrm{NH}_{4}^{+}$to $\mathrm{H}^{+}$in the apoplast). This method has been used successfully in several experimental and modeling studies (Flechard and Fowler 1998; Schjoerring et al. 1998; Milford et al. 2001; Sparks et al. 2008).
The transport of leaf-surface $\mathrm{NO}_{3}{ }^{-}$and $\mathrm{NH}_{4}{ }^{+}$ions primarily occurs through cuticular diffusion (Peuke et al. 1998). The indirect evidence for this stems from the observation that $\mathrm{NH}_{4}{ }^{+}$leaf uptake is higher than $\mathrm{NO}_{3}{ }^{-}$leaf uptake in most tracer experiments (e.g., Garten and Hanson 1990; Peuke et al. 1998). Our current understanding of plant cuticles suggests cations are transported much more readily through cuticles than anions (Tyree et al. 1990). Plant cuticles tend to be positively charged at $\mathrm{pH}$ values $>3$ (Schonherr and Bukovac 1973) and negatively charged ions are excluded from cuticular diffusion.

A mechanism for stomatal transport has been presented. Burkhardt and Eiden (1994) suggested continuous water layers connect the leaf surface to the mesophyll through the stomata during wetting allowing the diffusion of ions. However, this hypothesis has not been fully tested to date.

Relative magnitude compared to other sources of $\mathrm{N}$

Determining the relative magnitude of foliar incorporation of $\mathrm{N}$ compared to soil-derived $\mathrm{N}$ has been challenging. Sievering et al. (2007) have suggested that nearly $50 \%$ of the $\mathrm{N}$ demand of a forest in Colorado, USA, is met by canopy incorporation of reactive $\mathrm{N}$. However, this is one of the highest estimates seen in the literature and canopy uptake of reactive $\mathrm{N}$ is variably reported as $0-50 \%$ of plant $\mathrm{N}$ demand (e.g., see review of Harrison et al. 2000). The variability of such estimates is probably driven by two factors: the inherent challenges in estimating canopy uptake from throughfall measurements, and an incomplete closure of the $\mathrm{N}$ budget at any given site. Although variable, the estimates of canopy uptake do suggest it is a consequential pathway for $\mathrm{N}$ entry into ecosystems.

At the whole-plant level, Vallano and Sparks (2007) used combined fumigation/hydroponic systems and isotopic tracers to estimate that up to $16 \%$ of total plant growth $\mathrm{N}$ can be derived from atmospheric $\mathrm{NO}_{2}$. This agreed relatively well with earlier modeled estimates by Muller et al. (1996) and Ammann et al. (1999). This study considered only one chemical species of reactive $\mathrm{N}$ and it is likely the sum of all potential foliar inputs of $\mathrm{N}$ would be higher and could potentially match those reported in some field throughfall estimates.

\section{Phytotoxicity versus airborne nutrition}

Laboratory estimates of phytotoxicity compared to field observations

All plant foliage is sensitive to reactive $\mathrm{N}$ at high enough concentrations (Wellburn 1990; Okano et al. 1990; Krupa 2003). However, at concentrations reflective of the current 
atmosphere (even in polluted areas) visible signs of phytotoxicity due to direct exposure are rarely observed or at least are not discernable from the influence of bulk deposition.

Field experiments have shown variable effects of leaf exposure to reactive $\mathrm{N}$ on overall plant growth with both increased and decreased growth rates observed (e.g., Adaros et al. 1991; Saxe 1994; Hufton et al. 1996). However, detrimental physiological responses including decreased photosynthesis (Saxe 1986), effects on plasma membranes (Russell et al. 1999) and plant water-use efficiency (Siegwolf et al. 2001) have been reported coincident with leaf fumigation with reactive $\mathrm{N}$.

Evidence for nutritive effects of foliar uptake in the field

There is significant debate about whether total $\mathrm{N}$ deposition to ecosystems significantly influences plant growth. Recent reviews suggest an enhanced growth effect of added $\mathrm{N}$ in both temperate and boreal forests of Europe and North America (Högberg 2007; Magnani et al. 2007). However, modeling efforts (Currie et al. 2004) based on long-term $\mathrm{N}$ addition experiments and shortterm ${ }^{15} \mathrm{~N}$ cycling studies (Nadelhoffer et al. 1999) suggest small to non-existent influences on plant growth. These efforts do not consider soil- and foliar-derived $\mathrm{N}$ separately. It would be intriguing to see if experiments which add reactive $\mathrm{N}$ to the soil surface would show increases in plant biomass if that $\mathrm{N}$ were applied to the canopy. However, large-scale experiments adding reactive $\mathrm{N}$ directly to the canopy are rare. The largest experiment to date was conducted at Howland Forest, Maine, USA where $\mathrm{NH}_{4} \mathrm{NO}_{3}$ was added to the forest canopy as a liquid mist. The impacts of this addition to growth have yet to be published (although see Gaige et al. 2007). Experiments like this one will shed some light on the influence of ion additions of $\mathrm{N}$ to the canopy. However, the simulation of the addition of all $\mathrm{N}$ to the canopy, including gases and particles, remains a challenge for the future.

\section{Why should foliar uptake of reactive $\mathrm{N}$ be considered separately from soil-deposited N?}

The level of atmospheric reactive $\mathrm{N}$ available for foliar uptake and total rates of $\mathrm{N}$ deposition are obviously related; higher atmospheric concentrations drive both processes. Therefore, the obvious question is: are there reasons the foliar uptake and soil deposition pathways should be considered separately?
Transport distances of reactive $\mathrm{N}$ compounds

Table 1 describes the atmospheric lifetimes of the dominant chemical species involved in both foliar uptake and bulk $\mathrm{N}$ deposition. The lifetime of a molecule in the table does not necessarily indicate time until chemical destruction, but considers the rate of deposition to the surface. The factors assumed in the lifetime estimate are listed in the footnotes to Table 1 .

Table 1 shows that there are significant differences among various forms of reactive $\mathrm{N}$ in lifetime and, hence, distances traveled from sources of emission. Further, the atmospheric chemistry of reactive N (Crutzen 1979) plays a significant role in transport distance. The primary emission compounds $\left(\mathrm{NO}, \mathrm{NO}_{2}\right.$, and $\left.\mathrm{NH}_{3}\right)$ undergo chemistry that significantly lengthens the distanced traveled before deposition or foliar uptake. $\mathrm{NO}$ and $\mathrm{NO}_{2}$ may react with oxidized hydrocarbons to form PAN. PAN is relatively stable in the atmosphere, deposits to the surface less readily than $\mathrm{NO}_{2}$, and allows reactive forms of oxidized $\mathrm{N}$ to be transported long distances. $\mathrm{NH}_{3}$ (a compound that deposits to the surface very rapidly and has an atmospheric lifetime of less than 1 day) is the only strongly basic compound in the atmosphere and readily reacts with acids in the atmosphere by reactions such as:

$2 \mathrm{NH}_{3}+\mathrm{H}_{2} \mathrm{SO}_{4} \Rightarrow\left(\mathrm{NH}_{4}\right)_{2} \mathrm{SO}_{4}$

Therefore, some portion of emitted $\mathrm{NH}_{3}$ is converted to $\mathrm{NH}_{4}^{+}$in the atmosphere, significantly extending its

Table 1 Chemical formula and atmospheric lifetime of the major $\mathrm{N}$-containing chemical species taken up directly by plant foliage

\begin{tabular}{lll}
\hline Chemical species & Chemical formula & $\begin{array}{l}\text { Atmospheric } \\
\text { lifetime }\end{array}$ \\
\hline Ammonia/ammonium & $\mathrm{NH}_{3} / \mathrm{NH}_{4}{ }^{+}$ & $1-10$ days $^{\mathrm{a}}$ \\
Nitric oxide & $\mathrm{NO}_{\text {Nitrogen dioxide }}$ & $57-600 \mathrm{~s}^{\mathrm{b}}$ \\
& $\mathrm{NO}_{2}$ & $143 \mathrm{~s}$ (daytime) \\
Nitrate radical & & $7 \mathrm{~h}$ (nighttime) \\
& $\mathrm{NO}_{3}$ & $5-6 \mathrm{~s}$ (daytime) \\
& & $>1,000 \mathrm{~s}$ (nighttime) \\
Nitric acid & $\mathrm{HNO}_{3}$ & 0.5 days $^{-1} \mathrm{~m}^{\mathrm{e}}$ \\
Peroxyacetyl nitrate (PAN) & $\mathrm{CH}_{3} \mathrm{C}(\mathrm{O}) \mathrm{O}_{2} \mathrm{NO}_{2}$ & $2-600 \mathrm{~h}^{\mathrm{f}}$ \\
\hline
\end{tabular}

${ }^{a}$ Estimates include lifetime of $\mathrm{NH}_{3}$ and particulate $\mathrm{NH}_{4}{ }^{+}$from $\mathrm{Er}-$ isman et al. (2007) and Schlesinger and Hartley (1992)

b Calculated for reactions with $\mathrm{O}_{3}$ and $\mathrm{HO}_{2}$ : reaction coefficients from Finlayson-Pitts and Pitts (2000)

${ }^{c}$ Reaction coefficients from Finlayson-Pitts and Pitts (2000)

${ }^{\mathrm{d}}$ Daytime zenith angle $=0^{\circ}$; nighttime $\tau$ calculated for reactions with $\mathrm{NO}_{2}$ and volatile organic compounds in an unpolluted atmosphere, from Brasseur et al. (1999)

e Includes heterogeneous incorporation into clouds and aerosols, from Brasseur et al. (1999)

${ }^{\mathrm{f}}$ Assuming no new PAN synthesis, from Singh et al. (1990) 
atmospheric lifetime as a particle, aerosol, or as an ion in water (Schlesinger and Hartley 1992). The effect of differential atmospheric lifetimes coupled with a nonrandom distribution of point sources suggests that sites arrayed across the landscape not only receive different amounts of total reactive $\mathrm{N}$ but also different proportions of chemical species in that deposition. In general, $\mathrm{NO}_{2}$ and $\mathrm{NH}_{3}$ will dominate deposition near point sources of emission, organic compounds like PAN will become more dominant further downwind after the air mass begins to oxidize, and highly oxidized forms like $\mathrm{HNO}_{3}$ will dominate fully oxidized air masses. This is, of course, a simplified view and does not consider several factors including the disassociation of PAN back to $\mathrm{NO}_{2}$ and the variability of air mass movement across the landscape. However, it is likely that different environments receive dramatically different amounts and compositions of reactive $\mathrm{N}$.

Foliar uptake is likely to be most important in environments dominated by reactive $\mathrm{N}$ compounds likely to enter plant stomata at a rate higher than deposit to other surfaces in the environment. This appears to be the case for $\mathrm{NO}_{2}$ (Sparks et al. 2001; Wellburn 2002), PAN (Sparks et al. 2003), and other forms of organic nitrate (Lockwood et al. 2008), but not the case for $\mathrm{NH}_{3}$ and $\mathrm{HNO}_{3}$ (Bytnerowicz et al. 1998; Nielsen et al. 2002). Therefore, the partitioning of total deposition between foliar uptake and deposition to other surfaces could be very different across environments.

The foliar incorporation pathway leads to a direct addition of $\mathrm{NO}_{3}{ }^{-}$and $\mathrm{NH}_{4}{ }^{+}$to metabolism

The pathway of direct foliar uptake of reactive $\mathrm{N}$ is clearly fundamentally different from uptake of $\mathrm{N}$ deposited to other surfaces in the environment. Long- and short-term studies of $\mathrm{N}$ application to the soil surface (Nadelhoffer et al. 1999; Currie et al. 2004; Pregitzer et al. 2008) have shown that at least some of the deposited $\mathrm{N}$ is incorporated into soil organic matter and has some likelihood of returning directly back to the atmosphere as a gas (through nitrification, denitrification, or volatilization) or being leached from the system and never being incorporated into plants. In contrast, foliar uptake is a direct addition to plant metabolism and competes with no other process in supporting plant growth.

Whether foliar uptake of $\mathrm{N}$ supports net growth likely depends on the balance between plant $\mathrm{N}$ limitation and the phytotoxic effects of exposure. Phytotoxic effects are well documented for both $\mathrm{NH}_{3}$ (Krupa 2003) and oxides of $\mathrm{N}$ (Wellburn 1990). However, the concentrations where injury or decreased performance occur are usually well above the concentrations seen in all but the most polluted environments. It should be pointed out that the isolated effects of foliar uptake have been primarily assessed over short timescales and it is very likely long-term chronic influences on growth do occur.

Detrimental ecosystem-level effects of soil-added reactive $\mathrm{N}$

Chronic soil deposition of reactive $\mathrm{N}$ has a suite of potential detrimental effects including increases in $\mathrm{NO}_{3}{ }^{-}$ leaching and loss of base cations (Hultberg et al. 1994; Hedin et al. 1995), soil acidification (van Breeman et al. 1995), and forest decline (Aber 1992; Stoddard 1994; McNulty et al. 1996). Therefore, the growth response of plants to $\mathrm{N}$ deposition may be particularly sensitive to the partitioning between the foliar and soil pathways (i.e., the larger the proportion moving directly through foliage the larger the growth response).

\section{Ecosystem-level considerations}

Interaction with rising carbon dioxide concentrations

Consideration of foliar $\mathrm{N}$ uptake is compelling against the backdrop of global increases in atmospheric carbon dioxide $\left(\mathrm{CO}_{2}\right)$. The debate over the general relationship between simultaneous increases in $\mathrm{CO}_{2}$ and reactive $\mathrm{N}$ is ongoing (Nadelhoffer et al. 1999; Högberg 2007) and the potential differential role of soil versus foliar incorporation of added $\mathrm{N}$ is not considered in most simulations (White et al. 2000; Pepper et al. 2005). Increases in available $\mathrm{N}$ at the site of carboxylation (i.e., the leaf) could potentially drive additional $\mathrm{C}$ gain in otherwise $\mathrm{N}$-limited sites. However, very little experimental evidence exists for such a scenario.

Hufton et al. (1996) examined the combined influence of increased $\mathrm{CO}_{2}$ and $\mathrm{NO}+\mathrm{NO}_{2}$ fumigation in hydroponically grown lettuce and found a $20 \%$ increase in growth in plants experiencing the combined fumigation compared to elevated $\mathrm{CO}_{2}$ alone. The fumigation level of reactive $\mathrm{N}$ in this study was 10 times higher than that experienced by plants in the field (450 p.p.b.), but does suggest foliar uptake of $\mathrm{N}$ can influence growth under elevated $\mathrm{CO}_{2}$.

The influence of added $\mathrm{N}$ directly from the atmosphere to the apoplast is likely very complex. Bloom et al. (2001) observed $\mathrm{NO}_{3}{ }^{-}$accumulation in leaves under elevated $\mathrm{CO}_{2}$ in wheat and suggested multiple mechanisms whereby $\mathrm{NO}_{3}{ }^{-}$assimilation is inhibited under elevated $\mathrm{CO}_{2}$. This suggests that the effect of additional $\mathrm{NO}_{3}{ }^{-}$from foliar uptake may either be unimportant under elevated $\mathrm{CO}_{2}$ (if inhibition of $\mathrm{NO}_{3}{ }^{-}$is severe) or that the higher apoplastic concentrations of $\mathrm{NO}_{3}{ }^{-}$generated by foliar uptake may offset the slower rate of assimilation. 


\section{Herbivory}

Increased atmospheric $\mathrm{CO}_{2}$ levels have often been linked to herbivory through changes in leaf $\mathrm{N}$ content leading to increased levels of herbivory (e.g., Coviella and Trumble 1999; Hunter 2001). There is some debate as to whether this phenomenon occurs predictably in the field (Hamilton et al. 2004), but, if true, foliar uptake of $\mathrm{N}$ is likely to strongly influence this relationship.

A common observation of plants under fumigation by reactive $\mathrm{N}$ is an increase in at least some aspects of leaf $\mathrm{N}$ (Rowland 1986; Rowland et al. 1987; Segschneider et al. 1995; Hanstein et al. 1999; Takahashi et al. 2005) and there is some level of correspondence between natural variation in foliar uptake and leaf $\mathrm{N}$ contents (Calanni et al. 1999; Tomaszewski and Sievering 2007; Sievering et al. 2007). Therefore, foliar uptake has the potential to alter the stoichiometry of $\mathrm{C}$ and $\mathrm{N}$ in plant tissues in opposition to that driven by elevated $\mathrm{CO}_{2}$. This would likely have an influence on herbivory and should be experimentally tested in the future.

\section{$\mathrm{N}$-limited ecosystems}

Many of the potential influences of foliar uptake of $\mathrm{N}$ compounds as highlighted in this review are focused on $\mathrm{N}$-limited environments where the added $\mathrm{N}$ may have some influence on plant growth. $\mathrm{N}$ (and other nutrient) limitations to plant growth are common in many landscapes (Field 2001), but the likely impact of $\mathrm{N}$ deposition in general and the foliar uptake of $\mathrm{N}$ in particular must be interpreted in the context of the limitations to growth. For example, the influence of $\mathrm{N}$ deposition and the foliar uptake of $\mathrm{N}$ will be strongly modulated by water availability in arid and semi-arid regions. Most field research to date has largely focused on either $\mathrm{N}$-limited ecosystems or ecosystems receiving large amounts of reactive $\mathrm{N}$ deposition due to human activities. Much less is known about the influence of overall $\mathrm{N}$ deposition and foliar uptake in non$\mathrm{N}$-limited/low deposition ecosystems.

\section{Measurements at different levels of integration}

\section{Scaling from leaf-level measurements}

As with all leaf-level physiological measurements, scaling up from estimates derived from single leaves is very challenging. Part of the problem is simply the extrapolation of small errors in precision. Small percentage errors in leaflevel measurements are compounded when extrapolated to whole plants and canopies. Further, leaf and branch measurements of foliar uptake often utilize a cuvette or enclosure that, despite sophisticated levels of control, differs in many regards to the natural environment.

Despite these difficulties, the largest knowledge base regarding foliar uptake of reactive $\mathrm{N}$ comes from smallscale measurements and should be utilized in larger-scale process models and experiments. Currently, laboratory and field measurements have generated leaf-area specific flux rates for NO (e.g., Hereid and Monson 2001; Teklemariam and Sparks 2006), $\mathrm{NO}_{2}$ (e.g., Thoene et al. 1996; Weber and Rennenberg 1996; Gessler et al. 2000, 2002; Sparks et al. 2001; Eller and Sparks 2006), $\mathrm{NH}_{3}$ (e.g., Fangmeier et al. 1994; Hanstein et al. 1999; Ashraf et al. 2003; Castro et al. 2006), PAN (e.g., Sparks et al. 2003; Teklemariam and Sparks 2004), and HONO (e.g., Schimang et al. 2006). Direct estimates of leaf uptake of $\mathrm{HNO}_{3}$ and ionic and particulate forms of $\mathrm{NO}_{3}{ }^{-}$and $\mathrm{NH}_{4}{ }^{+}$are less well resolved (e.g., Hanson and Taylor 1990; Burkhardt and Eiden 1994; Bytnerowicz et al. 1998; Peuke et al. 1998) and only first approximation estimates can currently be made. Many of the uptake estimates listed above can be expressed over a range of plant species, ambient gas concentrations and stomatal conductances. Until larger integration estimates are made (see below), leaf-level uptake estimates should be used to partition $\mathrm{N}$ additions to ecosystems between foliar and soil pathways in process models.

\section{Throughfall measurements}

In the early 1990s, Lovett and Lindberg (1993) examined precipitation and canopy throughfall chemistry at sites across Europe and North America and estimated that $\sim 40 \%$ of all $\mathrm{N}$ deposited is retained by the canopy. Since that time, studies have interpreted the difference between total deposition (wet and dry) to the canopy and throughfall to be a measurement of canopy retention and potential assimilation of reactive $\mathrm{N}$ into plant biomass (e.g., Balestrini and Tagliaferri 2001; Gaige et al. 2007). Recently, Sievering et al. (2007) have put forth the idea of canopy $\mathrm{N}$ uptake (CNU) and related estimates of CNU to net ecosystem exchange of $\mathrm{C}$ (NEE). This general concept may be an integrated way to approach the relationship between foliar incorporation of $\mathrm{N}$ and plant growth. However, several shortcomings currently limit the usefulness of this approach. First, it remains difficult to link canopy retention to assimilation. For example, preliminary measurements from a large canopy-level application of ${ }^{15} \mathrm{~N}$ label to a forest in Maine indicated less than $5 \%$ of the label was recovered in live foliage and wood after 2 years of $\mathrm{N}$ addition to the canopy (Dail et al., in review). Second, most throughfall-based analyses do not account for gaseous losses of $\mathrm{N}$ from the canopy. We know that significant phytolysis of reactive $\mathrm{N}$ yielding gaseous losses occurs from snow and ice (Dibb et al. 1998; Munger et al. 1999; 
Beine et al. 2002) and recent evidence suggests similar phytolytic losses occur from plant canopies (Raivonen et al. 2006). Such gaseous losses would cause canopy uptake estimates to decrease. Third, it has not been demonstrated the $\mathrm{N}$ added through $\mathrm{CNU}$ can influence physiology at the timescale Sievering et al. (2007) use for comparison to NEE. These authors use NEE and CNU estimates from time periods corresponding to the time between precipitation events (the timescale necessary for a canopy throughfall measurement). Often these time periods are short (a few to several days) and it is unclear if $\mathrm{N}$ assimilated into the canopy can influence physiology at this timescale.

\section{Micrometeorological measurements}

Perhaps some of the most powerful methods for assessing the integrated deposition of $\mathrm{N}$ are micrometeorological methods such as eddy covariance and relaxed eddy accumulation. These and other meteorological methods have been used to quantify fluxes of various components of reactive N to plant canopies (Pryor et al. 2001; Riedo et al. 2002; Pryor and Klemm (2004); Butterbach-Bahl et al. 2004; Farmer et al. 2006; Turnipseed et al. 2006). However, it is challenging to separate the foliar incorporation component from the overall flux estimate generated using these methods. Downward fluxes to canopies are the summation of deposition to surfaces, foliar (stomatal) deposition, and chemical destruction. The estimate is also strongly influenced by meteorological conditions (Baldocchi and Wilson 2001). Therefore, although meteorological methods can provide robust estimates of the fluxes of reactive $\mathrm{N}$, additional information is needed to partition this flux among different pathways of deposition and chemical destruction.

Appropriate experiments for informing future modeling efforts

Modeling estimates of the global enhancement of forest growth due to atmospheric reactive $\mathrm{N}$ deposition vary dramatically between 0.1 and $2 \mathrm{Pg} \mathrm{C}_{\text {year }}{ }^{-1}$ (Schindler and Bayley 1993; Townsend et al. 1996; Holland et al. 1997). Most of these efforts simply assume growth enhancement is proportional to $\mathrm{N}$ deposition and do not necessarily differentiate foliar incorporation from soildeposited N.

The information most useful to process modeling is a reasonable partitioning of deposited $\mathrm{N}$ among pathways leading to plant assimilation (soil vs. foliar) and estimates of how this deposited $\mathrm{N}$ increases plant growth across a variety of ecosystems.
Producing these estimates will require a combination of ecosystem and fine-scale physiology measurements. Ideally, meteorological measurements of flux and leaf-level uptake measurements could be co-located at focal sites and coordinated with laboratory measurements of dominant plant species. A research science plan suggestive of such a strategy has been presented by a workshop aimed at increasing understanding of atmosphere-biosphere $\mathrm{N}$ interactions (Holland et al. 2005).

\section{Important future research directions}

Determine the relationship between instantaneous plant performance and foliar uptake of reactive $\mathrm{N}$

Physiological responses to foliar incorporation of reactive $\mathrm{N}$ have been studied (see "Physiological ecology of foliar uptake" and "Phytotoxicity versus airborne nutrition" above). However, several important questions have rarely been addressed. Does the availability of reactive $\mathrm{N}$ to leaves influence short- and long-term photosynthetic capacity? What is the cost associated with overcoming the phytotoxic effects of the incorporation of reactive $\mathrm{N}$ by leaves and does it increase rates of respiration? How does the net effect of physiological alteration influence plant growth?

Advances in technology for determining dry $\mathrm{N}$ deposition

The monitoring of wet deposition is done routinely at many sites. However, the monitoring of dry deposition is much rarer. The best regional estimates of dry $\mathrm{N}$ deposition within North America come from the Environmental Protection Agency sponsored Clean Air Status and Trends Network (CASTNet) sites. However, CASTNet sites only measure a subset of dry-deposited $\mathrm{N}$ (particulate $\mathrm{NO}_{3}{ }^{-}$and $\mathrm{NH}_{4}{ }^{+}$and gas-phase $\mathrm{HNO}_{3}$ ) and do not quantify several important species of gaseous $\mathrm{N}$ (e.g., $\mathrm{NH}_{3}$, and major components of total $\mathrm{NO}_{y}$ including $\mathrm{NO}_{2}$, dinitrogen pentoxide, HONO, PANs, and alkyl nitrates). In addition, CASTNet sites are relatively rare. Similar monitoring networks exist in Europe with many of the same problems. New technologies for the monitoring of dry deposition of reactive $\mathrm{N}$ are needed for any scaling exercise of both total $\mathrm{N}$ deposition and foliar uptake.

Examination of the affects of foliar $\mathrm{N}$ uptake under increased $\mathrm{CO}_{2}$ concentrations

As discussed in "Interaction with rising carbon dioxide concentrations", some evidence exists that direct foliar 
incorporation of reactive $\mathrm{N}$ may increase the growth of plants under elevated $\mathrm{CO}_{2}$. However, this relationship has not been tested rigorously and has only been examined in very few plant species. If a synergistic relationship exists between canopy uptake of reactive $\mathrm{N}$ and plant growth, the influence on $\mathrm{C}$ sequestration is potentially large and should be quantified in multiple plant functional types.

Develop methods for partitioning between foliar and root $\mathrm{N}$ uptake

Partitioning of deposited $\mathrm{N}$ among pathways of incorporation (foliar vs. soil) will be key to our future understanding of the influence of $\mathrm{N}$ deposition on ecosystem productivity. It is unlikely any single method can be used to determine this partitioning. However, a combination of methods that quantify total $\mathrm{N}$ deposition, rates of foliar uptake of various compounds, and the influence of incorporation on plant growth could be used to determine partitioning in key ecosystems.

Incorporation of the foliar uptake of reactive $\mathrm{N}$ into regional and global production models

As discussed in "Appropriate experiments for informing future modeling efforts", current process models either do not consider foliar uptake of reactive $\mathrm{N}$ separate from total $\mathrm{N}$ deposition or make this separation without firm experimental evidence. Given the potential differences between soil- and canopy-deposited $\mathrm{N}$, a future research priority should be to reasonably partition these pathways in process models.

\section{Conclusions}

In the past 30 years, large strides forward have been made in our understanding of the leaf uptake of reactive N. More work is needed to elucidate the leaf uptake mechanisms of ionic, particulate, and organic forms, but we do understand the basic mechanisms of uptake for the dominant inorganic forms $\left(\mathrm{NO}, \mathrm{NO}_{2}, \mathrm{NH}_{3}\right.$ ) of reactive $\mathrm{N}$. However, similar strides have not been made in determining the ecological importance of foliar uptake. It is still unclear when or if foliar uptake enhances plant growth and what the direct connections are between uptake and physiological processes like photosynthesis.

Foliar uptake of reactive $\mathrm{N}$ is likely very different from the acquisition of $\mathrm{N}$ by plants after soil deposition and should be considered differently in ecosystem process modeling. In order to facilitate this, research priority should be placed on combined ecosystem and physiology studies aimed at accurately partitioning the entry of reactive $\mathrm{N}$ into ecosystems between foliar and soil pathways.

\section{References}

Aber JD (1992) Nitrogen cycling and nitrogen saturation in temperate forest ecosystems. Trends Ecol Evol 7:220-224

Aber JD, Goodale CL, Ollinger SV, Smith M, Magill AH, et al (2003) Is nitrogen deposition altering the nitrogen status of northeastern forests? Bioscience 53:375-389

Adaros G, Weigel HJ, Jäger HJ (1991) Single and interactive effects of low levels of $\mathrm{O}_{3}, \mathrm{SO}_{2}$ and $\mathrm{NO}_{2}$ on the growth and yield of spring rape. Environ Pollut 72:269-286

Ammann M, Siegwolf RTW, Pichelmayer F, Suter M, Saurer M, Brunold C (1999) Estimating the uptake of traffic derived $\mathrm{NO}_{2}$ from ${ }^{15} \mathrm{~N}$ abundance in needles of Norway spruce. Oecologia 118:124-131

Ashraf M, Mahmood T, Azam F (2003) Translocation and recovery of ${ }^{15} \mathrm{~N}$-labelled $\mathrm{N}$ derived from foliar uptake of ${ }^{15} \mathrm{NH}_{3}$ by rice (Oryza sativa L.) cultivars. Biol Fertil Soils 38:257-260

Baldocchi DD, Wilson K (2001) Forest canopies as sources and sinks of atmospheric trace gases: scaling up to ecosystem level. In: Gasche R, Papen H, Rennenberg H (eds) Trace gas exchange in forest ecosystems. Kluwer, Boston, pp 229-242

Balestrini R, Tagliaferri A (2001) Atmospheric deposition and canopy exchange processes in alpine forest ecosystems (northern Italy). Atmos Environ 35(36):6421-6433

Beine HA, Honrath RE, Dominé F, Simpson WR, Fuentes JD (2002) Snow-pile and chamber experiments during the polar sunrise experiment 'alert 2000': exploration of nitrogen chemistry. Atmos Environ 36:2707-2719

Bender J, Weigel H, Jager H (1991) Response of nitrogen-metabolism in beans (Phaseolus vulgaris L.) after exposure to ozone and nitrogen dioxide, alone and in sequence. New Phytol 119:261-267

Bloom AJ, Meyerhoff PA, Taylor AR, Rost TL (2001) Root development and absorption of ammonium and nitrate from the rhizosphere. J Plant Growth Regul 21:416-431

Bobbink R, Heil GW, Raessen MBAG (1992) Atmospheric deposition and canopy exchange processes in heathland ecosystems. Environ Pollut 75:29-41

Bowden RD, Geballe GT, Bowden WB (1989) Foliar uptake of ${ }^{15} \mathrm{~N}$ from simulated cloud water by red spruce (Picea rubens) seedlings. Can J For Res 19:382-386

Boyce R, Friedland A, Chamberlain C, Poulson S (1996) Direct canopy uptake from ${ }^{15} \mathrm{~N}$-labeled wet deposition by mature red spruce. Can J For Res 26:1539-1547

Brasseur GP, Orlando JJ, Tyndall GS (1999) Atmospheric chemistry and global change. Oxford University Press, New York

Burkhardt J, Eiden R (1994) Thin water films on coniferous needles (with an appendix 'a new device for the study of water vapour condensation and gaseous deposition to plant surfaces and particle samples' by J Burkhardt and J Gerchau). Atmos Environ 28:2001-2017

Butterbach-Bahl K, Kesik M, Miehle P, Papen H, Li C (2004) Quantifying the regional source strength of N-trace gases across agricultural and forest ecosystem with process based models. Plant Soil 260:311-329

Bytnerowicz A, Percy K, Riechers G, Padgett P, Krywult M (1998) Nitric acid vapor effects on forest trees-deposition and cuticular changes. Chemosphere 36:697-907

Calanni J, Berg E, Wood M, Mangis D, Boyce R, Weathers W, et al (1999) Atmospheric nitrogen deposition at a conifer forest: 
response of free amino acids in Englemann spruce needles. Environ Pollut 105:79-89

Castro A, Stulen I, Posthumus FS, de Kok LJ (2006) Changes in growth and nutrient uptake in Brassica oleracea exposed to atmospheric ammonia. Ann Bot 97:121-131

Coviella CE, Trumble JY (1999) Effects of elevated atmospheric $\mathrm{CO}_{2}$ on insect-plant interactions. Conserv Biol 13(8):1-13

Cowling E, Galloway J, Furiness C, Barber M, Bresser T, et al (2001) Optimizing nitrogen management in food and energy production and environmental protection. Proceedings of the 2nd International Nitrogen Conference on Science and Policy. Sci World 1(S2):1-9

Crutzen PJ (1979) The role of $\mathrm{NO}$ and $\mathrm{NO}_{2}$ in the chemistry of the troposphere and stratosphere. Annu Rev Earth Planet Sci 7:443472

Currie WS, Nadelhoffer NJ, Aber JD (2004) Redistributions of ${ }^{15} \mathrm{~N}$ highlight turnover and replenishment of mineral soil organic $\mathrm{N}$ as a long-term control on forest $\mathrm{C}$ balance. For Ecol Manage 196:109-127

Dasch JM (1989) Dry deposition of sulphur dioxide or nitric acid to oak, elm, and pine leaves. Environ Pollut 59:1-16

Davidson CI, Wu C-L (1990) Dry deposition of particles and vapors. In: Lindberg SE, Page AL, Norton SA (eds) Acidic precipitation. Springer, New York, pp 103-215

Dibb JE, Talbot RW, Munger JW, Jacob DJ, Fan SM (1998) Air-snow exchange of $\mathrm{HNO}_{3}$ and $\mathrm{NO}_{y}$ at Summit, Greenland. J Geophys Res 103:3475-3486

Dugger WM, Koukol J, Reed WD, Palmer RL (1963) Effect of peroxyacetyl-nitrate on $\mathrm{CO}_{2}$ fixation by spinach chloroplasts and pinto bean plants. Plant Physiol 38:468-473

Duyzer JH, Dorsey JR, Gallagher MW, Pilegaard K, Walton S (1994) Oxidized nitrogen and ozone interaction with forests. II. Multilayer process-oriented modeling results and a sensitivity study for Douglas fir. Quart J R Meteorol Soc 130:1957-1971

Eller ASD, Sparks JP (2006) Predicting leaf-level fluxes of $\mathrm{O}_{3}$ and $\mathrm{NO}_{2}$ : the relative roles of diffusion and biochemical processes. Plant Cell Environ 29:1742-1750

Erisman JW, Bleeker A, Galloway J, Sutton MS (2007) Reduced nitrogen in ecology and the environment. Environ Pollut 150:140-149

Fangmeier A, Hadwiger-Fangmeier A, Van der Eerden L, Jager HJ (1994) Effects of atmospheric ammonia on vegetation-a review. Environ Pollut 86:43-82

Farmer DK, Wooldridge PJ, Cohen RC (2006) Application of thermal-dissociation laser induced fluorescence (TD-LIF) to measurement of $\mathrm{HNO}_{3}$, Lalkyl nitrates, $\Sigma$ peroxy nitrates, and $\mathrm{NO}_{2}$ fluxes using eddy covariance. Atmos Chem Phys Discuss $6: 1-42$

Field CB (2001) Plant physiology of the "missing" carbon sink. Plant Physiol 125(1):25-28

Finlayson-Pitts BJ, Pitts JN (2000) Chemistry of the upper and lower atmosphere. Theory, experiments and applications. Academic Press, San Diego

Flechard CR, Fowler D (1998) Atmospheric ammonia at a moorland site. I. The meterological control of ambient ammonia concentrations and the influence of local sources. Quart J R Meteorol Soc 124:733-757

Gaige E, Dail DB, Hillinger DY, Davidson EA, Fernandez IJ, et al (2007) Changes in canopy processes following whole-forest nitrogen fertilization of a mature spruce-hemlock forest. Ecosystems 10:1133-1147

Galloway JN, Aber JD, Erisman JW, Seitzinger SP, Howarth RW, et al (2003) The nitrogen cascade. Bioscience 53:341-356

Galloway JN, Dentener FJ, Capone DG, Boyer EW, Howarth RW, et al (2004) Nitrogen cycles: past, present, and future. Biogeochemistry 70:153-226
Galloway JN, Townsend AR, Erisman JW, Bekunda M, Cai ZC, Freney JR, Martinelli LA, Seitzinger SP, Sutton MA (2008) Transformations of the nitrogen cycle: recent trends, questions, and potential solutions. Science 320(5878):889-892

Garten CTJR, Hanson PJ (1990) Foliar retention of nitrogen-15 nitrate and nitrogen-15 ammonium by red maple (Acer rubrum) and white oak (Quercus alba) leaves from simulated rain. Environ Exp Bot 30:333-342

Gessler A, Rennenberg H (1998) Atmospheric ammonia: mechanisms of uptake and impacts on N metabolism of plants. In: De Kok LJ, Studen I (eds) Responses of plant metabolism to air pollution and global change. Backhuys, Leiden, pp 81-94

Gessler A, Rienks M, Rennenberg $\mathrm{H}$ (2000) $\mathrm{NH}_{3}$ and $\mathrm{NO}_{2}$ fluxes between beech trees and the atmosphere-correlation with climatic and physiological parameters. New Phytol 147:539560

Gessler A, Rienks M, Rennenberg H (2002) Stomatal uptake and cuticular adsorption contribute to dry deposition of $\mathrm{NH}_{3}$ and $\mathrm{NO}_{2}$ to needles of adult spruce (Picea abies) trees. New Phytol 156:179-194

Grundmann GL, Lensi R, Chalamet A (1993) Delayed $\mathrm{NH}_{3}$ and $\mathrm{N}_{2} \mathrm{O}$ uptake by maize leaves. New Phytol 124(2):259-263

Gut A, Scheibe M, Rottenberger S, Rummel U, Welling M (2002) Exchange fluxes on $\mathrm{NO}_{2}$ and $\mathrm{O}_{3}$ at soil and leaf surfaces in an Amazonian rain forest. J Geophys Res-Atmos 107:8057

Haberer K, Jaeger L, Rennenberg H (2006) Seasonal patterns of ascorbate in needles of Scots pine (Pinus sylvestris L.) trees: correlation analyses with atmospheric $\mathrm{O}_{3}$ and $\mathrm{NO}_{2}$ gas mixing rations and meteorological parameters. Environ Pollut 139:224231

Hamilton JG, Zangerl AR, Berenbum MR, Pippen J, Aldea M, DeLucia E (2004) Insect herbivory in an intact forest understory under experimental $\mathrm{CO}_{2}$ enrichment. Oecologia 18:566-573

Hanson PJ, Lindberg S (1991) Dry deposition of reactive nitrogencompounds - a review of leaf, canopy, and non-foliar measurements. Atmos Environ 25A:1615-1634

Hanson PJ, Taylor GE Jr (1990) Modeling pollutant gas by leaves: an approach based on physiochemical properties. In: Dixon RK, Meldahl R, Ruark G, Warren WG (eds) Process modeling of forest growth response to environmental stress. Timber Press, Oregon

Hanstein S, Mattsson M, Jaeger H-J, Schjoerring JK (1999) Uptake and utilization of atmospheric ammonia in three native Poaceae species: leaf conductances, composition of apoplastic solution and interactions with root nitrogen supply. New Phytol 141:7183

Hargreaves KJ, Fowler D, Storetonwest R, Duyzer J (1992) The exchange of nitric-oxide, nitrogen-dioxide and ozone between pasture and the atmosphere. Environ Pollut 75:53-59

Harrison A, Schulze ED, Gebauer G, Bruckner G (2000) Canopy uptake and utilization of atmospheric pollutant nitrogen. In: Schulze ED (ed) Carbon and nitrogen cycling in European forest ecosystems. Springer, Berlin, pp 171-188

Hedin LO, Armesto JJ, Johnson AH (1995) Patterns of nutrient loss from unpolluted, old-growth forests: evaluation of biogeochemical theory. Ecology 76(2):493-509

Hereid DP, Monson RK (2001) Nitrogen oxide fluxes between corn (Zea mays L.) leaves and the atmosphere. Atmos Environ 35:975-983

Herrmann B, Jones SK, Fuhrer J, Feller U, Neftel A (2001) N budget and $\mathrm{NH}_{3}$ exchange of a grass/clover crop at two levels of $\mathrm{N}$ application. Plant Soil 235:243-252

Hill AC, Bennett JH (1970) Inhibition of apparent photosynthesis by nitrogen oxides. Atmos Environ 4:341-348

Högberg P (2007) Environmental science: nitrogen impacts on forest carbon. Nature 447:781-782 
Holland EA, Lamarque J-F (1997) Modeling bio-atmospheric coupling of the nitrogen cycle through $\mathrm{NO}_{x}$ emissions and $\mathrm{NO}_{y}$ deposition. Nutr Cycl Agroecosyst 48:7-24

Holland EA, Braswell BH, Lamarque JF, Townsend A, Sulzman J, Muller JF, Dentener F, Brasseur G, Levy H, Penner JE, Roelofs GJ (1997) Variations in the predicted spatial distribution of atmospheric nitrogen deposition and their impact on carbon uptake by terrestrial ecosystems. JGR Atmos 102(D3):1584915866

Holland EA, Bertman SB, Carroll MA, Guenther AB, Shepson PB, et al (2005) US nitrogen science plan focuses collaborative efforts. Eos 86(27):253-260

Hufton CA, Besford RT, Wellburn AR (1996) Effects of NO $\left(+\mathrm{NO}_{2}\right)$ pollution on growth, nitrate reductase activities and associated protein contents in glasshouse lettuce grown hydroponically in winter with $\mathrm{CO}_{2}$ enrichment. New Phytol 133:495-501

Hultberg H, Dise NB, Wright RF, Andersson I, Nyström U (1994) Nitrogen saturation induced during winter by experimental $\mathrm{NH}_{4}$ $\mathrm{NO}_{3}$ addition to a forested catchment. Environ Pollut 84(2):145147

Hunter MD (2001) Insect population dynamics meets ecosystem ecology: effects of herbivory on soil nutrient dynamics. Agric For Entomol 3:77-84

Hur JS, Wellburn A (1994) Effects of atmospheric $\mathrm{NO}_{2}$ on AzollaAnamaena symbiosis. Ann Bot 73:137-141

Janson R, Granat L (1999) A foliar rinse study of the dry deposition of nitric acid to a coniferous forest. Agric For Meteorol 98-99:683696

Krupa SV (2003) Effects of atmospheric ammonia $\left(\mathrm{NH}_{3}\right)$ on terrestrial vegetation: a review. Environ Pollut 124:179-221

Lea PJ, Miflin BJ (1974) An alternative route for nitrogen assimilation in higher plants. Nature 251:614-616

Lea PJ, Wolfenden J, Wellburn AR (1994) Influence upon air pollutants upon nitrogen metabolism. In: Alscher R, Wellburn AR (eds) Plant responses to gaseous environments. Chapman and Hall, London, pp 279-299

Lelieveld J, Dentener FJ (2000) What controls tropospheric ozone? J Geophys Res 105:3531-3552

Lerdau MT, Munger LJ, Jacob DJ (2000) Atmospheric chemistrythe $\mathrm{NO}_{2}$ flux conundrum. Science 289:2291

Lockwood AL, Filley TR, Rhodes D, Shepson PB (2008) Foliar uptake of atmospheric organic nitrates. Geophys Res Lett 35:L15809

Lovett GM, Lindberg SE (1993) Atmospheric deposition and canopy interactions of nitrogen in forests. Can J For Res 32:1603-1616

Lovett GM, Lindberg SE, Richter DD, Johnson DW (1985) The effects of acidic deposition on cation leaching from three deciduous forest canopies. Can J For Res 15:1055-1060

Magnani F, Mencuccini M, Borgheti M, Berbigier P, Beringer F, et al (2007) The human footprint in the carbon cycle of temperate and boreal forests. Nature 447:849-851

Marshall JD, Cadle SH (1989) Evidence for trans-cuticular uptake of $\mathrm{HNO}_{3}$ vapor by foliage or eastern white pine (Pinus strobus L.). Environ Pollut 60:15-28

McNulty SG, Aber JD, Newman SD (1996) Nitrogen saturation in a high elevation spruce-fir stand. For Ecol Manage 84:109-121

Meyers TP, Huebert BJ, Hicks BB (1989) $\mathrm{HNO}_{3}$ deposition to a deciduous forest. Bound Layer Meteorol 49:395-410

Miflin BJ, Habash DZ (2002) The role of glutamine synthetase and glutamate dehydrogenase in nitrogen assimilation and possibilities for improvement in the nitrogen utilization of crops. J Exp Bot 53:979-987

Milford C, Theobald MR, Nemitz E, Sutton MA (2001) Dynamics of ammonia exchange in response to cutting and fertilizing in an intensively-managed grassland. Water Air Soil Pollut $1: 167-176$
Monson RK, Holland EA (2001) Biospheric trace gas fluxes and their control over troposhperic chemistry. Annu Rev Ecol Syst 32:547-576

Muller B, Touraine B, Rennenberg H (1996) Interaction between atmospheric and pedospheric nitrogen nutrition in spruce (Picea abies L. Karst) seedlings. Plant Cell Environ 19:345-355

Munger JW, Jacob DJ, Fan S-M, Colamn AS, Dibb JE (1999) Concentrations and snow-atmosphere fluxes of reactive nitrogen at Summit, Greenland. J Geophys Res 104:13721-13734

Murray A, Wellburn A (1985) Differences in nitrogen-metabolism between cultivars of tomato and pepper during exposure to glasshouse atmospheres containing oxides of nitrogen. Environ Pollut Ser A Ecol Biol 39:303-316

Nadelhoffer KL, Emmett BA, Gundersen P, Kjonaas PJ, Koopmans CJ, et al (1999) Nitrogen deposition makes a minor contribution to carbon sequestration in temperate forests. Nature 398:145148

Nemitz E, Sutton MA, Schoerring JK, Husted S, Wyers GP (2000) Resistance modeling of ammonia exchange over oilseed rape. Agic For Meteorol 105:405-425

Nielsen KO, Schjorring JK, Erisman JW, Pearson J (2002) Exchange of trace gases at the tree-atmosphere interface: ammonia exchange at the tree-atmosphere interface. In: Gasche R, Papen $\mathrm{H}$, Rennenberg $\mathrm{H}$ (eds) Trace gas exchange in forest ecosystems. Kluwer, Boston, pp 159-173

Okano K, Machida T, Totsuka T (1990) Foliar uptake of peroxyacetyl nitrate (PAN) by herbaceous species varying in susceptibility to this pollutant. New Phytol 114:139-145

Pepper DA, Del Grosso SJ, McMurtrie RE, Parton WJ (2005) Simulated carbon sink response of shortgrass steppe, tallgrass prairie and forest ecosystems to rising $\left[\mathrm{CO}_{2}\right]$, temperature and nitrogen input. Global Biogeochem Cycles 19:125-138

Peuke AD, Jesche WD, Dietz K-J, Schreiber L, Hartung W (1998) Foliar application of nitrate and ammonium as sole nitrogen supply in Ricinus communis. I. Carbon and nitrogen uptake and inflows. New Phytol 138:675-687

Pregitzer KS, Burton AJ, Zak DR, Talhelm AF (2008) Simulated chronic nitrogen deposition increases carbon storage in northern temperate forests. Global Chang Biol 14:142-153

Pryor SC, Klemm O (2004) Experimentally derived estimates of nitric acid dry deposition velocity and viscous sub-layer resistance at a conifer forest. Atmos Environ 38:2769-2777

Pryor SC, Barthelmie RJ, Sorensen LL, Jensen B (2001) Ammonia concentrations and fluxes over a forest in the Midwestern USA. Atmos Environ 35:5645-5656

Pryor SC, Anlauf K, Boudries H, Hayden K, Schiller CL, Weibe A (2004) Spatial and temporal variability of high resolution reduced nitrogen concentrations in the Fraser Valley. Atmos Environ 38:5825-5836

Qiao Z, Murray F (1997) The effects of root nitrogen supplies on the absorption of atmospheric $\mathrm{NO}_{2}$ by soybean leaves. New Phytol 136(2):239-243

Raivonen M, Bonn B, José Sanz M, Vesala T, Kulmala M, Hari P (2006) UV-induced $\mathrm{NO}_{y}$ emissions from Scots pine: could they originate from photolysis of deposited $\mathrm{HNO}_{3}$ ? Atmos Environ 40:6201-6213

Ramge P, Badeck F-W, Ploechl M, Kohlmaier GH (1993) Apoplastic antioxidants as decisive elimination factors within the uptake process of nitrogen dioxide into leaf tissues. New Phytol 125:7185

Remmler JL, Campbell W (1986) Regulation of corn leaf nitrate reductase. 2 . Synthesis and turnover of the enzymes activity and protein. Plant Physiol 80:442-447

Rhodes D, Brunk DG, Magelhaes JR (1989) Assimilation of ammonia by glutamate dehydrogenase. In: Poulton JE, Romeo JT, Con EE (eds) Plant metabolism. Plenum, New York, pp 191-226 
Riedo M, Milford C, Schmid M, Sutton MA (2002) Coupling soilplant-atmosphere exchange of ammonia with ecosystem functioning in grasslands. Ecol Model 158:83-110

Rowland AJ (1986) Nitrogen uptake, assimilation and transport in barley in the presence of atmospheric nitrogen dioxide. Plant Soil 91:353-356

Rowland AJ, Drew M, Wellburn A (1987) Foliar entry and incorporation of atmospheric nitrogen-dioxide into barley plants of different nitrogen status. New Phytol 107:357-371

Russell CE, Pittman J, Darrall NM, Williams LE, Hall JL (1999) Effects of air pollution on proton and sucrose transport at the plasma membrane of Ricinus communis. Plant Cell Environ 22:221-227

Saxe H (1986) Stomatal-dependent and stomatal-independent uptake of $\mathrm{NO}_{x}$. New Phytol 103(1):199-205

Saxe H (1994) Relative sensitivity of greenhouse pot plants to longterm exposure of $\mathrm{NO}$ - and $\mathrm{NO}_{2}$-containing air. Environ Pollut 85:283-290

Schimang R, Folkers A, Kleffmann J, Kleist E, Miebach M, Wildt J (2006) Uptake of gaseous nitrous acid (HONO) by several plant species. Atmos Environ 40:1324-1335

Schindler DW, Bayley SE (1993) The biosphere as an increasing sink for atmospheric carbon-estimates from increased nitrogen deposition. Global Biogeochem Cycles 7:717-733

Schjoerring JK, Husted S, Mattson M (1998) Physiological parameter controlling plant-atmosphere ammonia exchange. Atmos Environ 32:491-498

Schlesinger WH, Hartley AE (1992) A global estimate for atmospheric $\mathrm{NH}_{3}$. Biogeochemistry 15:191-211

Schonherr J, Bukovac MJ (1973) Ion exchange properties of isolated tomato fruit cuticular membrane: exchange capacity, nature of fixed charges and cation selectivity. Planta 109:73-93

Segschneider H-J, Wildt J, Forstel H (1995) Uptake of ${ }^{15} \mathrm{NO}_{2}$ by sunflower (Helianthus annuus) during exposures in light and darkness: quantities, relationship to stomatal aperture and incorporation into different nitrogen pools within the plant. New Phytol 131:109-119

Siegwolf RTW, Matyssek R, Saurer M, Maurer S, Günthardt-Goerg S, et al (2001) Stable isotope analysis reveals differential effects of soil nitrogen and nitrogen dioxide on the water use efficiency in hybrid popular leaves. New Phytol 149:233-246

Sievering H, Kelly T, McConville G, Seibold C, Turnipseed A (2001) Nitric acid dry deposition to conifer forests: Niwot Ridge sprucefir-pine study. Atmos Environ 35:3851-3859

Sievering H, Tomasewski T, Torizzo J (2007) Canopy uptake of atmospheric $\mathrm{N}$ deposition at a conifer forest. Part I. Canopy $\mathrm{N}$ budget, photosynthetic efficiency and net ecosystem exchange. Tellus 59B:483-492

Singh HB, Cordon E, Vedder J, O'Hara D, Ridley BA, et al (1990) PAN measurements during CITE. 2. Atmospheric distribution and precursor relationships. J Geophys Res 95(10):163-178

Sparks JP, Monson RK, Sparks KL, Lerdau MT (2001) Leaf uptake of nitrogen dioxide $\left(\mathrm{NO}_{2}\right)$ in a tropical wet forest: implications for tropospheric chemistry. Oecologia 127:214-221

Sparks JP, Roberts JM, Monson RK (2003) Uptake of gaseous organic nitrogen by leaves: a significant global nitrogen transfer process. Geophy Res Lett 30:2189

Sparks JP, Walker J, Turnipseed A, Guenther A (2008) Dry nitrogen deposition over a forest experiencing free air $\mathrm{CO}_{2}$ enrichment. Global Chang Biol 14(4):768-781

Spierings $\mathrm{F}$ (1971) Influence of fumigations with $\mathrm{NO}_{2}$ on growth and yield of tomato plants. Neth J Plant Pathol 77:194-200

Srivastava HS, Singh RP (1987) Role and regulation of glutamate dehydrogenase activity in higher pants. Phytochemistry 26:597610
Stoddard JL (1994) Long-term changes in watershed retention of nitrogen. Its causes and aquatic consequences. In: Baker LA (ed) Environmental chemistry of lakes and resources. American Chemical Society, Washington, pp 223-284

Stulen I, ter Steege M (1995) Light and nitrogen assimilation. In: Srivastava HS, Singh RP (eds) Nitrogen nutrition in higher plants. Associated Publishing, New Delhi, pp 367-384

Stulen I, Pere-Soba M, De Kok LJ, van der Eerden L (1998) Impact of gaseous nitrogen deposition on plant functioning. New Phytol 139(1):61-70

Sutton MA, Milford C, Dragosits U, Place CJ, Singles RJ, et al (1998) Dispersion, deposition, and impacts of atmospheric ammonia: quantifying local budgets and spatial variability. Environ Pollut 102:349-361

Takahashi M, Higaki A, Nohno M, Kamada M, Okamura Y, et al (2005) Differential assimilation of nitrogen dioxide by 70 taxa of roadside trees at an urban pollution level. Chemosphere 61:633639

Taylor GE, Hanson E Jr, Baldocchi DD (1988) Pollution deposition to individual leaves and plant canopies: site of regulation and relationship to injury. In: Heck WW, Taylor OC, Tinge DT (eds) Assessment of crop loss from air pollutants. Elsevier, Amsterdam, pp 227-257

Teklemariam TA, Sparks JP (2004) Gaseous fluxes of peroxyacetyl nitrate (PAN) into plant leaves. Plant Cell Environ 27:1149_ 1158

Teklemariam TA, Sparks JP (2006) Leaf fluxes of $\mathrm{NO}$ and $\mathrm{NO}_{2}$ in four herbaceous plant species: the role of ascorbic acid. Atmos Environ 40:2235-2244

Thoene B, Schröder P, Papen H, Egger A, Rennenberg H (1991) Absorption of atmospheric $\mathrm{NO}_{2}$ by Spruce (Picea abies L. Karst.) trees I. $\mathrm{NO}_{2}$ influx and its correlation with nitrate reduction. New Phytol 117:575-585

Thoene B, Rennenberg H, Weber P (1996) Absorption of atmospheric $\mathrm{NO}_{2}$ by Spruce (Picea abies) trees. II. Parameterization of $\mathrm{NO}_{2}$ fluxes by controlled dynamic chamber experiments. New Phytol 134:257-266

Tischner R (1987) Regulation of ammonium incorporation. In: Ullrich WR, Aparicio PJ, Syrett PJ, Castillo F (eds) Inorganic nitrogen metabolism. Springer, Berlin, pp 126-131

Tomaszewski T, Sievering H (2007) Canopy uptake of atmospheric $\mathrm{N}$ deposition at a conifer forest. Part II. Response of chlorophyll florescence and gas exchange parameters. Tellus 59:493-501

Townsend AR, Braswell BH, Holland EA, Penner JE (1996) Spatial and temporal patterns in terrestrial carbon storage due to deposition of fossil fuel nitrogen. Ecol Appl 6:806-814

Turnipseed AA, Huey LG, Nemitz E, Stickel R, Higgs J, et al (2006) Eddy covariance fluxes of peroxyacetyl nitrates (PANs) and $\mathrm{NO}_{y}$ to a coniferous forest. J Geophys Res 111:1245-1257

Tyree MT, Scherbatskoy TD, Tabor CA (1990) Leaf cuticles behave as asymmetric membranes. Evidence from the measurement of diffusion potentials. Plant Physiol 92:103-109

Vallano DM, Sparks JP (2007) Foliar $\delta^{15} \mathrm{~N}$ values as indicators of foliar uptake of atmospheric nitrogen pollution. In: Dawson TE, Siegwolf TW (eds) Stable isotopes as indicators of ecological change. Academic Press, New York, pp 93-109

van Aardenne JA, Dentener FJ, Olivier JGJ, Lelieveld J (2001) A $1^{\circ} \times 1^{\circ}$ resolution data set of historical anthropogenic trace gas emissions for the period 1890-1990. Global Biogeochem Cycles 15:909-928

van Breeman N, Finlay R, Lundström U, Jongmans AG, Giesler R, Olsson M (1995) Mycorrhizal weathering: a true case of mineral plant nutrition? Biogeochemistry 49:53-67

Von Liebig J (1827) Sur la nitrification. Ann Chim Phys 35:329 
Vose J, Swank W (1990) Preliminary estimates of foliar absorption of ${ }^{15} \mathrm{~N}$-labeled nitric acid $\left(\mathrm{HNO}_{3}\right)$ by eastern white pine (Pinus strobus). Can J For Res 20:857-863

Wallsgrove RM (1987) The roles of glutamine synthetase and glutamate synthase in nitrogen metabolism of higher plants. In: Ullrich WR, Aparicio PJ, Syrett PJ, Castillo F (eds) Inorganic nitrogen metabolism. Springer, Berlin, pp 137-141

Weber P, Rennenberg H (1996) Dependency of nitrogen dioxide $\left(\mathrm{NO}_{2}\right.$ ) fluxes to wheat (Triticum aestivum L.) leaves from $\mathrm{NO}_{2}$ concentrations, light intensity, temperature and relative humidity determined from controlled dynamic chamber experiments. Atmos Environ 30:3001-3009

Wellburn AR (1990) Why are atmospheric oxides of nitrogen usually phytotoxic and not alternative fertilizers? New Phytol 115:395429
Wellburn AR (2002) Biological processes involved in trace gas exchange: $\mathrm{NO}_{2}, \mathrm{NO}$, and $\mathrm{HNO}_{3}$ uptake by trees. In: Gasche R, Papen $\mathrm{H}$, Rennenberg $\mathrm{H}$ (eds) Trace gas exchange in forest ecosystems. Kluwer, Boston, pp 35-52

Wellburn AR, Majernik O, Wellburn FAM (1972) Effects of $\mathrm{SO}_{2}$ and $\mathrm{NO}_{2}$ polluted air upon the ultrastructure of chloroplasts. Environ Pollut 3:37-49

White A, Cannel MGR, Friend AD (2000) The high-latitude terrestrial carbon sink: a model analysis. Global Chang Biol 6:227-245

Wyers GP, Erisman JW (1998) Ammonia exchange over coniferous forests. Atmos Environ 32:441-451

Zeevaart AJ (1976) Some effects of fumigating plants for short periods with $\mathrm{NO}_{2}$. Environ Pollut 11:97-108 